\title{
Perspektif Hukum Islam mengenai Konsep Keluarga Sakinah dalam Keluarga Karir
}

\author{
Mesta Wahyu Nita \\ IAI Agus Salim Lampung, Indonesia \\ E-mail: tanitawahyu17@gmail.com
}

\begin{abstract}
Article Info
Article History

Received: 2021-12-27

Revised: 2022-01-22

Published: 2022-02-15

Abstract

This study describes the study of the perspective of Islamic law regarding the concept of a sakinah family in a career family. The method used in this study uses a library research method or approach, that library research can be interpreted as a series of activities related to the methods of collecting library data, reading and taking notes and processing research materials. The results of this study indicate that a sakinah family is

Keywords:

Perspective;

Islamic Law;

Sakinah Family; defined as a harmonious family where the values of Islamic teachings are always upheld and mutual respect and love for each other. In a sakinah family, family members are able to carry out their obligations and always help each other. However, due to economic factors, a wife works to help the family economy. Although Islamic teachings strongly encourage women to take care of their families and households, this does not prevent them from playing an active role in building and empowering communities together with men in real life without neglecting their duties and maintaining the household and maintaining the good manners of women leaving their homes. in terms of clothing or otherwise.
\end{abstract}

\begin{tabular}{l}
\hline Artikel Info \\
\hline Sejarah Artikel \\
Diterima: $2021-12-27$ \\
Direvisi: 2022-01-22 \\
Dipublikasi: $2022-02-15$
\end{tabular}

Kata kunci:

Perspektif; Hukum Islam; Keluarga Sakinah; Keluarga Karir.

\begin{abstract}
Abstrak
Penelitian ini menjelaskan tentang kajian terhadap perspektif hukum islam mengenai konsep keluarga sakinah dalam keluarga karir. Metode yang digunakan dalam kajian ini menggunakan metode atau pendekatan kepustakaan (library research), bahwa studi pustaka atau kepustakaan dapat diartikan sebagai serangkaian kegiatan yang berkenaan dengan metode pengumpulan data pustaka, membaca dan mencatat serta mengolah bahan penelitian. Hasil penelitian ini menunjukkan bahwa keluarga yang sakinah diartikan sebagai keluarga yang harmonis dimana nilai-nilai ajaran Islam senantiasa ditegakkan dan saling menghormati serta saling menyayangi. Dalam keluarga yang sakinah, anggota keluarga mampu menjalankan kewajibannya dan senatiasa membantu satu sama lain. Namun karena faktor ekonomi, seorang istri bekerja membantu ekonomi keluarga. Meski ajaran islam sangat menganjurkan perempuan untuk menjaga keluarga dan rumah tangganya, namun hal tersebut tidak menghalangi untuk berperan aktif dalam membangun dan memberdayakan masyarakat bersama-sama dengan lelaki dalam kehidupan nyata tanpa melalaikan tugas dan menjaga rumah tangga serta tetap menjaga adab keluarnya wanita dari rumahnya baik dalam hal pakaian ataupun lainnya.
\end{abstract}

\section{PENDAHULUAN}

Hukum Islam meliputi segala aspek kehidupan manusia, baik untuk mewujudkan kebahagian dunia maupun kebahagian di akhirat kelak, manusia diciptakan sebagai mahkluk sosial, yaitu mahkluk yang tidak bisa hidup sendiri dan membutuhkan orang lain didalam mengarungi bahtera kehidupan (Tanjung, 2020). Salah satu jalan mengarungi kehidupan adalah dengan mengarungi pernikahan, islam mendorong untuk membentuk keluarga, Islam mengajak manusia untuk hidup dalam naungan keluarga, karena keluarga seperti gambaran kecil dalam kehidupan stabil yang menjadi pemenuhan keinginan manusia, tanpa menghilangkan kebutuhannya (As-Subki, 2012). Islam merupakan agama yang sempurna, islam adalah agama pelengkap atau agama yang melengkapi aturan atau syariat dari agama sebelumnya (Na'im, 2021). Agama Islam mengatur tentang aturan-aturan (syariat) dalam kehidupan yang belum pernah ada atau belum pernah diatur oleh agama sebelum Islam, seperti dalam hal perkawinan. Menurut (Fasa, 2020) bahwa Islam mengaturnya bertujuan agar kehidupan sosial masyarakat menjadi tentram. Perkawinan atau pernikahan merupakan salah satu bagian terpenting dari siklus kehidupan manusia, pernikahan merupakan peristiwa sakral dalam kehidupan masyakat indonesia yag masih tetap menjunjung tinggi nilai adat dan agama yang beraneka ragam. Perkawinan merupakan sunatullah bagi manusia sebagai sarana untuk melangsungkan garis keturunan selain itu perkawinan atau pernikahan merupakan sunah 
nabiyyallah Muhammad Saw. Seperti dalam salah satu hadits Nabi yang berbunyi "Nikah itu merupakan sunah ku, barang siapa yang membenci sunah ku maka ia bukan dari golonganku" (Thobibatussaadah, 2013).

Menurut al-Thabari penciptaan perempuan dari tulang rusuk, sebagai kelanjutan penciptaan Adam dari tahah, kemudian ini dijadikan landasan untuk membina rumah tangga melalui perkawinan, sehingga perkawinan dilakukan dengan tujuan untuk mendapatkan ketenangan mawaddah dan rahmah (Thobibatussaadah, 2013), dalam memaknai kata mawaddah dan rahmah, Ulama berbeda pendapat tentang hal ini. Menurut Ibnu Abbas dan Mujahid yang dimaksud dengan mawaddah adalah al-jima' atau hubungan suami istri dan al-rahmah adalah nak (walad), dengan demikian bahwa tujuan perkawinan yang dikehendaki Al-Quran adalah ketenangan hidup, adanya perlindungan, untuk menciptakan hidup yang tenang dengan cara saling mencintai dan mengasihi secara intens. Salah satu wujud ketenangan dalam keluarga juga adalah kehadiran anak yang dapat mempererat ikatan suami istri. Keluarga merupakan unit terkecil masyarakat, bila setiap keluarga merasa tentram dan nyaman, satu sama lain saling menyayangi, maka masyarakat yang terbentuk juga merupakan masyarakat yang tentram dan saling menyayangi dan menghormati, sehingga masyarakat ideal yang dicita-citakan setiap umat manusia akan terwujud. Aspek lain untuk mewujudkan tujuan perkawinan dalam Al-Quran diatas bahwa perkawinan harus dilakukan dengan memenuhi syarat dan rukun perkawinan, dimaklumi bersama yang menjadi rukun perkawinan adalah calon mempelai, dua orang saksi, adanya wali nikah, dan ijab qabul. Rukun nikah ini diharapkan dapat menjamin keabsahan nikah. Selain itu, legalitas pernikahan harus dijamin melalui perundang-undangan yang ditetapkan negara (Thobibatussaadah, 2013).

Dalam mengimplementasikan syariat Islam dalam suatu keluarga, dibutuhkan faktor-faktor dan banyak lagi hal lain yang mendukung terwujudnya keluarga sakinah seperti yang diharapkan oleh semua manusia. Diantara faktor agar terimplementasikannya syariat Islam dipengaruhi oleh pendidikan orang tua dan anak, selain itu juga lingkungan sangat mempengaruhi implementasi syariat Islam tersebut, untuk mencapai sesuatu pasti dengan cara berangsur-angsur atau dengan bertaha, karena untuk mendapatkan suatu hal yang maksimal, maka dibutuhkan suatu jalan yang ditempuh melalui langkah demi langkah, dimana langkah ini maka terwujudlah suatu perubahan yang terarah kepada pembaruan, maka ia akan berarah pada aksi atau aktivitas (Arifudin, 2020). Problem lain kerumahtanggaan yakni masalah ekonomi, kekurangan finansial dapat berpengaruh besar pada kualitas keluarga. Menurut (Labetubun, 2021) bahwa finansial menjadi faktor pendukung dalam kebahagiaan rumah tangga, hal ini yang biasanya membuat alasan istri bekerja membantu ekonomi keluarga, dengan istri yang berkarier sering diasumsikan akan mengganggu keharmonisan rumah tangga. Meninggalkan rumah karena sibuk bekerja, bisa memicu konflik rumah tangga, suasana hangat di rumah yang didambakan oleh suami ketika ia pulang dari pekerjaan, akan tidak didapat lagi bila istrinya masih bekerja di luar rumah, meski ajaran islam sangat menganjurkan perempuan untuk menjaga keluarga dan rumah tangganya, namun hal tersebut tidak menghalanginya untuk berperan aktif dalam membangun dan memberdayakan masyarakat bersama-sama dengan lelaki dalam kehidupan nyata tanpa melalaikan tugas dan menjaga rumah tangga.

Dewasa ini juga telah terbuka bagi kaum perempuan, mereka dapat bekerja di ruang publik, dunia kerja publik sudah bisa dimasuki oleh kaum perempuan baik yang masih lajang maupun yang sudah bersuami, baik Al-Qur'an maupun hadits Nabi sama sekali tidak melarang mereka bekerja demikian, dengan kata lain islam tidak memberikan batasan-batasan ruang untuk kerja perempuan maupun laki-laki masingmasing bisa kerja di dalam maupun di luar rumah dan dalam semua bidang yang baik yang di butuhkan untuk kelangsungan hidup yang baik pula, meski demikian pandangan dan perlakuan sebagian besar masyarakat terhadap perempuan masih saja diskriminatif, berdasarkan latar belakang di atas, maka penelit tertarik untuk melakukan kajian pustaka terhadap Perspektif Hukum Islam Mengenai Konsep Keluarga Sakinah dalam Keluarga Karir.

\section{METODE PENELITIAN}

Sesuai dengan karakteristik masalah yang diangkat dalam penelitan ini maka menggunakan Metode Riset kualitatif, yaitu menekankan analisanya pada data deskriptif berupa kata-kata tertulis yang diamati, pendekatan kualitatif penulis gunakan untuk menganalisis kajian terhadap perspektif hukum islam mengenai konsep keluarga sakinah dalam keluarga karir. Maka dengan sendirinya penganalisaan data ini lebih 
difokuskan pada Penelitian Kepustakaan (Library Research), yakni dengan membaca, menelaah dan mengkaji buku-buku dan sumber tulisan yang erat kaitannya dengan masalah yang dibahas. Metode yang digunakan dalam kajian ini menggunakan metode atau pendekatan kepustakaan (library research), menurut Zed dalam (Rahayu, 2020) bahwa studi pustaka atau kepustakaan dapat diartikan sebagai serangkaian kegiatan yang berkenaan dengan metode pengumpulan data pustaka, membaca dan mencatat serta mengolah bahan penelitian.

Jenis penelitian ini adalah penelitian kualitatif, menurut Ibnu dalam (Tanjung, 2022) penelitian kualitatif adalah suatu penelitian yang datanya dinyatakan dalam bentuk verbal dan dianalisis tanpa menggunakan teknik statistik, berdasarkan beberapa definisi penelitian kualitatif di atas, dapat disimpulkan bahwa penelitian kualitatif adalah suatu penelitian yang datanya dinyatakan dalam bentuk verbal, tidak menggunakan angka dan analisisnya tanpa menggunakan teknik statistik.

\section{Objek Penelitian}

Dalam penelitian ini objek penelitian terdiri dari 2 (dua), yaitu objek formal dan objek material (Bairizki, 2021). Objek formal dalam penelitian ini berupa data yaitu data yang berhubungan dengan tinjauan kritis kajian terhadap perspektif hukum islam mengenai konsep keluarga sakinah dalam keluarga karir, sedangkan objek materialnya berupa sumber data, dalam hal ini adalah tinjauan kritis kajian terhadap perspektif hukum islam mengenai konsep keluarga sakinah dalam keluarga karir.

2. Waktu Penelitian

Penelitian ini dilaksanakan pada bulan November sampai dengan Desember tahun 2021.

3. Teknik Pengumpulan Data

Pengumpulan data yang dilakukan dengan menggunakan teknik dokumentasi yaitu mengadakan survey bahan kepustakaan untuk mengumpulkan bahan-bahan dan studi literatur yakni mempelajari bahan-bahan yang berkaitan dengan objek penelitian, teknik pengumpulan data menurut (Bahri, 2021) mengemukakan bahwa merupakan langkah yang paling strategis dalam penelitian karena tujuan untama dari penelitian adalah mendapatkan data. Terdapat beberapa cara atau teknik dalam mengumpulkan data, diantaranya adalah observasi dan dokumentasi. Sumber data yang digunakan dalam penelitian ini mencakup data primer dan sekunder. Menurut (Hanafiah, 2021) bahwa data primer adalah data yang dikumpulkan langsung dari individu-individu yang diselidiki atau data tangan pertama. Sedangkan data sekunder adalah data yang ada dalam pustaka-pustaka, data primer dalam penelitian ini adalah bukubuku terkait tinjauan kritis kajian terhadap perspektif hukum islam mengenai konsep keluarga sakinah dalam keluarga karir, dan data sekunder didapatkan dari jurnal-jurnal baik nasional maupun internasional.

4. Alat Pengumpulan Data

Dalam penelitian ini, penulis akan menggunakan metode dokumentasi sebagai alat untuk pengumpul data karena penelitian ini adalah penelitian kepustakaan. Dengan kata lain, menurut (Febrianty, 2020) bahwa teknik ini digunakan untuk menghimpun data-data dari sumber primer maupun sekunder.

5. Teknik Analisis Data

Analisis data tidak saja dilakukan setelah data terkumpul, tetapi sejak tahap pengumpulan data proses analisis telah dilakukan, penulis menggunakan strategi analisis "kualitatif", strategi ini dimaksudkan bahwa analisis bertolak dari data-data dan bermuara pada kesimpulan-kesimpulan umum. Berdasarkan pada strategi analisis data ini, dalam rangka membentuk kesimpulan-kesimpulan umum analisis dapat dilakukan menggunakan kerangka pikir "induktif", menurut (Sugiyono, 2015) bahwa metode pembahasan menggunakan metode deskriptif-analisis, yaitu menjelaskan serta mengelaborasi ide-ide utama yang berkenaan dengan topik yang dibahas, kemudian menyajikannya secara kritis melalui sumber-sumber pustaka primer maupun skunder yang berkaitan dengan tema.

6. Prosedur Penelitian

Data pada penelitian ini dicatat, dipilih dan kemudian diklasifikasikan sesuai dengan kategori yang ada, pendekatan yang digunakan adalah pendekatan deskriptif analitis. Menurut (Siregar, 2021) bahwa deskriptif analitis (descriptive of analyze research), yaitu pencarian berupa fakta, hasil dari ide pemikiran seseorang melalui cara mencari, menganalisis, membuat interpretasi serta melakukan generalisasi terhadap hasil penelitian yang dilakukan. Prosedur penelitian ini adalah untuk menghasilkan data deskriptif yang berupa data tertulis setelah melakukan analisis pemikiran (content analyze) dari suatu teks, setelah penulis mengumpulkan bahan- 
bahan yang berhubungan dengan masalah yang akan dibahas dalam penelitian ini, kemudian penulis menganalisis dan menarasikan untuk diambil kesimpulan.

\section{HASIL DAN PEMBAHASAN}

Dalam pembahasan ini akan dibahas tentang konsep keluarga dalam hukum islam, keluarga sakinah, dan Berbagai Pendapat Hukum Wanita Karir

1. Konsep Keluarga Dalam Hukum Islam

Islam mendorong untuk membentuk keluarga, Islam mengajak manusia untuk hidup dalam naungan keluarga, karena keluarga seperti gambaran kecil dalam kehidupan stabil yang menjadi pemenuhan keinginan manusia tanpa menghilangkan kebutuhannya, keluarga me-rupakan tempat fitrah yang sesuai dengan keinginan Allah SWT bagi kehidupan manusia sejak keberadaan khalifah (As-Subki, 2012). Konsep keluarga menurut Islam secara sub-stansial yaitu membentuk rumah tangga yang bernafaskan Islam, yang sakinah (kedamaian), mawaddah (tenteram), warahmah (kasih sayang). Tujuan ini yang ingin di cari dalam sebuah rumah tangga dengan tercapainya konsep ini, maka rumah tangga yang harmonis dan bahagia berlandaskan syariat Allah akan mudah di jalani, hanya pada poin-poin tertentu yang memberi penekanan yang lebih dalam pelaksanaannya, seperti hal-hal yang menyangkut tentang hak dan kewajiban atau peran suami istri di dalam rumah tangga. Islam mewajibkan suami terhdap istrinya memberikan hak-hak yang harus di penuhinya sebagai hak istri (As-Subki, 2012). Hakhak suami terhadap istrinya yang diwajibkan oleh Islam memungkinkan perempuan melaksanankan tanggung jawabnya yang pokok dalam rumah dan masyarakat, memberi kemampuan bagi laki-laki untuk membangun rumahnya dan keluarganya. Diantara hak-hak dan kewajiban-kewajiban suami adalah mahar dan Nafkah, Pendidikan dan pengajaran, Adil dalam berinteraksi, Kesenangan yang bebas, Tidak cemburu berlebihan, dan Berprasangka baik pada istri (As-Subki, 2012). Seseorang yang berfikir atas dorongan Islam dalam mewujudkan dan memenginginkan berkeluarga, ia akan memperhatikan dengan penuh kejelasan dan mendapatkannya tanpa letih terhadap bebagai tugas terpenting dan tujuan berkeluarga menurut Islam, diantara sebagai berikut: a) Kemulian Keturunan.

Berketerunan merupakan hal pokok, oleh karena itu pernikahan dilakukan, yang dimaksudkan ialah menjaga keturunan dan melestarikan jenis manusia di dunia, dengan perantara anak, akan mendekatkan seseorang pada empat macam. Keempat macam tersebut merupakan pokok yang diinginkan ketika merasa aman dari keburukan syahwat, sehingga salah satunya tidak mengingin berjumpa kepada Allah dalam keadaaan menbujang: 1) mengikuti kecintaan Allah SWT dengan berusaha memperoleh anak agar jenis menusia terpelihara, 2) mengharap cinta Rasulullah SAW dalam memperbanyak keturunan sebagai kebanggan Nabi, 3) mengharap keberkahan dengan doa anak shaleh setelah kematiaannya, 4) mencari syafaat dengan meninggalnya anak kecil jika ia meninggal sebelumnya (As-Subki, 2012).

b) Menjaga Diri Dari Setan.

Hubungan seksual yang diperintahkan antara suami dan istri dapat menjaga dirinya dari tipu daya setan, melemahkan keberingasan, mencegah keburukan-keburukan syahwat, memelihara pandangan, dan menjaga kelamin, berkaitan dengan hal ini, Nabi SAW mengisyaratkan dengan sabdany "Barang siapa yang menikah sungguh ia telah menjaga setengah agamanya, maka bertakwalah kepada Allah SWT" (Arifin, 2005).

c) Bekerjasama Dalam Menghadapi Kesulitan Hidup

Ikatan pernikahan adalah ikatan selamanya, oleh karena itu pernikahan tidak terbatas karena suatu hal yang terhenti karenanya pernikahan membentuk keluarga selamanya, tujuan keluarga adalah keteguhan dan ketenangan. Seorang lakilaki yang bekerja keras, bersungguhsungguh, bepergian, pulang kembali, berperang dan berdamai, ia tidak mungkin mengerjakan hal-hal tersebut menurut pandangan yang benar tanpa seorang istri shalehah bersamanya, menggembirakannya, membuatnya sedih, meringankan kesedihannya, memperhatikan rumah istri dan anakanaknya. Nabi SAW bersabda "Sungguh dunia semua ini perhiasan, sebaik-baik perhisan adalah istri yang yang shalehah", oleh karena itu bekerja sama dalam menanggung berbagai beban hidup 
antara suai istri termasuk salah satu tujuan keluarga dalam Islam (Arifin, 2005).

d) Menghibur Jiwa Dan Menenengkannya Dengan Bersama-sama sesungguhnya kenyamanan jiwa dan ketenangan dengan bersama-sama, memandang dan bermainmain, menyegarkan hati, dan menguatkannya untuk beribadah sebagai sesuatu yang diperintahkan, jiwa yang gelisah menjadi enggan pada kebenaran karena kebenaran bersebrangan dengan tabiat nafsu, jika nafsu dibebani secara terus menerus dengan paksaan pada sesuatu yang bersebrangan dengannya mak ia menadi keras kepala dan kokoh. Jika nafsu disegerakan dengan kenikmatan pada waktu tertentu maka ia menjadi kuat dan bergairah. Bersahabat dengan perempuan termasuk istirahat yang menghilangkan kesempitan dan menyegarkan hati, sepantasnya bagi jiwa orang-orang yang bertakwa untuk menyegarkannya dengan hal-hal mubah (Saebani, 2013).

e) Melaksanakan Hak-Hak Keluarga.

Melawan nafsu melatihnya dengan tanggung jawab, kekuasaan, melaksanakan hakhak keluarga, sabar atas akhlak, menanggung keburukannya, berusaha memperbaikinya, menunjukkan mereka pada jalan agama, bersungguh-sungguh dalam melakukan pekerjaan yang halal, melaksanakan pendidikan baginya dan bagi anak-anaknya, semua ini adalah amal perbuatan yang mulia dan utama.

f) Pemindahan Kewarisan.

Tidak mungkin ada konsep perpindahan kekayaan dari generasi kegenerasi dengan tanpa adanya wadah yang memelihara nasab, kerabat dan keturunan, wadah ini adalah keluarga. Al-Quran yang mulia telah menjelaskan kaidah-kaidah warisan antar kerabat, hal tersebut tidak akan kokoh dengan sempurna tanpa adanya hubungan kekerabatan yang jelas dan batasanbatasan tertentu (As-Subki, 2012).

g) Masalah-Masalah Lainnya, Keluarga memiliki banyak tujuan yang tidak disebutkan, antara lain keharaman zina yakni perbuatan yang kita ketahui sebagai kekejian besar yang dilarang Allah SWT untuk melakukannya bahkan untuk mendekatinya dan semua hal yang menyebabkan terjadinya zina (Sinta, 2003).

\section{Keluarga Sakinah}

Keluarga adalah unit terkecil dari suatu masyarakat, bila tidak ada keluarga, dengan kata lain, masyarakat merupakan kumpulan keluarga-keluarga (Sofyan, 2020), ini berarti baik buruknya suatau masyarakat tergantung pada baik buruknya masyarakat kecil itu (keluarga). Jadi keselamatan dan kebahagiaan suatu masyarakat berpangkal pada masyarakat terkecil atau keluarga (Saebani, 2013) dalam sebuah keluarga, penting bagi setiap pasangan untuk menjadikan keluarga sebagai tempat, memadu kasih sayang, cinta, kebersamaan, dan ketaqwaan kepada Allah SWT. Hal itu relevan dengan konsep keluarga yang terkait sebuah janji pernikahan suci kepada Allah SWT dan pasangan, maka dari pernikahan akan tumbuh kasih sayang sejati yang berakar dari sanubari, yang kokoh dan kuat dengan cabang yang teguh, membuahkan kesetian dan keserasian dalam istilah agama disebut pernikahan yang mawaddah wa rahmah atau keluarga sakinah (Enung, 2012). Mewujudkan keluarga sakinah mawaddah warahmah adalah merupakan kemaslahatan bagi setiap pasangan yang berumah tangga, Allah pun telah berfirman dalam kitabnya dalam surat Ar-Rum ayat 21 yang Artinya: "Dan di antara tanda-tanda kekuasaan-Nya ialah Dia menciptakan untukmu isteri-isteri dari jenismu sendiri, supaya kamu cenderung dan merasa tenteram kepadanya dan dijadikan-Nya diantara mu rasa kasih dan sayang, sesungguhnya pada yang demikian itu benar-benar terdapat tanda-tanda bagi kaum yang berfikir". Memang tidak mudah menentukan apakah sebuah keluarga itu bisa disebut sakinah, hal tersebut karena setiap orang mempunyai presepsi yang tidak sama dalm wujud suatu kebahagian. Aisjah Dachlan memberikan kriteria mengenai sebuah keluarga yang sakinah, sebagai berikut:

a) Saling pengertian antara suami istri.

b) Setia dan cinta mencintai.

c) Mampu menghadapi persoalan dan kesukaran.

d) Percaya mempercayai dan saling bentu membantu.

e) Dapat memahami kelemahan dan kekurangan masing-masing.

f) Lapang dada dan terbuka.

g) Selalu konsultasi dan musyawarah.

h) Hormat menghormati keluarga masingmasing. 
i) Dapat mengusahakan sumber kehidupan yang layak.

j) Mampu mendidik anak dan anggota keluarga lain (Mahmudah, 2011).

3. Berbagai Pendapat Hukum Wanita Karir

Dalam kamus besar bahaasa Indonesia, "wanita" berarti perempuan dewasa, sedangkan "karir" berarti yang berkecimpung dalam kegiatan profesi (usaha, perkantoran, dsb, karir adalah pekerjaan yang memberikan harapan untuk maju (Arifudin, 2019), oleh karena itu karir selalu dikaitkan dengan uang dan kuasa, namun bagi sebagian yang lain, masalah tentu bukan sekedar itu, karir juga merupakan karya yang tidak dapat dipisahkan dengan panggilan hidup bahagia. Secara definisi wanita karir bermakna seorang wanita yang menjadikan karir atau pekerjaan secara serius, perempuan yang memiliki karir atau yang menganggap kehidupan kerjanya dengan serius (mengalahkan sisi-sisi kehidupan yang lain), dalam Islam yang wajib memberikan nafkah adalah suami. Islam menjadikan suami sebagai kepala keluarga, dipundaknyalah tanggung jawab utama lahir batin keluarga, Islam juga sangat proporsional dalam membagi tugas rumah tangga, kepala keluarga diberikan tugas utama untuk menyelesaikan segala urusan diluar rumah, sedangkan sang istri memiliki tugas utama yang mulia, yakni mengurusi segala urusan dalam rumah (Zein, 2004). Meskipun wanita telah dianggap sederajat dengan pria namun bukan berarti seorang wanita saat bertindak seperti laki-laki, bebas keluar rumah dan eksis diranah publik, sebagai contoh perbedaan laki-laki dan wanita (yang akan berpengaruh dalam pekerjaan yang boleh untuk wanita dan yang tidak) adalah perbedaan fisik. Kadang sering dijumpai bahwa kondisi sebagian suami mereka ternyata tidak berkemampuan menanggung biaya hidup keluarga, bahkan kebanyakan orang tua/wali tidak sanggup menaggung beban hidup seorang anak wanita beserta anak-anaknya ketika ia diceraikan suaminya atau menjadi janda karena ditinggal mati oleh suaminya, dalam kondisi seperti ini seseorang wanita dapat dikatakan wajib terjun kedunia profesi (karir) untung menanggung biaya hidupnya beserta keluarganya karena sipenanggung jawab sudah tiada/ tidak berdaya, dengan pekerjaan yang halal tentunya (Nasution, 1994), adapun syarat diperbolehkannya wanita bekerja diluar rumah adalah menutup aurat, menghindari fitnah, mendapat izin dari orang tua, wali atau suami bagi yang sudah menikah, tetap menjalankan kewajibannya dirumah.

\section{SIMPULAN DAN SARAN}

\section{A. Simpulan}

Berdasarkan pemaparan pada penelitian perspektif hukum islam mengenai konsep keluarga sakinah dalam keluarga karir ini dapat disimpulkan bahwa keluarga yang sakinah diartikan sebagai keluarga yang harmonis dimana nilai-nilai ajaran Islam senantiasa ditegakkan dan saling menghormati serta saling menyayangi, dalam keluarga yang sakinah, anggota keluarga mampu menjalankan kewajibannya dan senantiasa membantu satu sama lain. Namun karena faktor ekonomi, seorang istri bekerja membantu ekonomi keluarga, meski ajaran islam sangat menganjurkan perempuan untuk menjaga keluarga dan rumah tangganya, namun hal tersebut tidak menghalangi untuk berperan aktif dalam membangun dan memberdayakan masyarakat bersama-sama dengan lelaki dalam kehidupan nyata tanpa melalaikan tugas dan menjaga rumah tangga serta tetap menjaga adab keluarnya wanita dari rumahnya baik dalam hal pakaian ataupun lainnya.

\section{B. Saran}

Pembahasan terkait penelitian kajian terhadap perspektif hukum islam mengenai konsep keluarga sakinah dalam keluarga karir dalam penelitian ini masih sangat terbatas dan membutuhkan banyak masukan. Saran untuk penulis selanjutnya adalah mengkaji lebih dalam dan secara komprehensif terkait kajian terhadap perspektif hukum islam mengenai konsep keluarga sakinah dalam keluarga karir.

\section{DAFTAR RUJUKAN}

Al-Brigawi. (2012). Fiqih Keluarga Muslim Rahasia Mengawetkan Bahtera Rumah Tangga. Jakarta: Amzah.

Arifin. (2005). Hukum Islam Solusi Permasalahan Keluarga. Yogyakarta: UII Press Yogyakarta.

Arifudin, O. (2021). Pengaruh Kelas Sosial, Pengalaman dan Gaya Hidup terhadap Perilaku Penggunaan Kartu Kredit. Jurnal 
Ilmiah MEA (Manajemen, Ekonomi, \& Akuntansi), 5(1), 286-298.

Arifudin, 0. (2020). Pengaruh Penjualan Personal Dan Lokasi Terhadap Volume Penjualan (Survey Pada Dealer Kamera Digital Panasonic Di Kota Bandung). Managament Insight: Jurnal Ilmiah Manajemen, 15(2), 232-241.

Arifudin, 0. (2019). Pengaruh Kompensasi Terhadap Kinerja Karyawan Di PT. Global (PT.GM). Jurnal Ilmiah MEA (Manajemen, Ekonomi, \& Akuntansi), 3(2), 184-190.

As-Subki. (2012). Fiqih Keluarga Pedoman Berkeluarga Dalam Islam. Jakarta: Amzah.

Bahri, A. S. (2021). Pengantar Penelitian Pendidikan (Sebuah Tinjauan Teori dan Praktis). Bandung: Widina Bhakti Persada.

Bairizki, A. (2021). Manajemen Perubahan. Bandung: Widina Bhakti Persada.

Enung. (2012). Implementasi Agama Dalam Mewujudkan Keluarga Sakinah: Kajian Hukum Islam Dan Sosial Kemasyarakatan. Purwokerto: IAIN Purwokerto dan Penerbit Komunika.

Fasa, I. (2020). Eksistensi Bisnis Islami Di Era Revolusi Industri 4.0. Bandung: Widina Bhakti Persada.

Febrianty, F. (2020). Kepemimpinan \& Prilaku Organisasi Konsep Dan Perkembangan. Bandung: Widina Bhakti Persada.

Haikal. (1993). Rahasia Perkawinan Rasulullah $S A W$. Jakarta: CV Pedoman Ilmu Jaya.

Hanafiah, H. (2021). Pelatihan Software Mendeley Dalam Peningkatan Kualitas Artikel Ilmiah Bagi Mahasiswa. Jurnal Karya Abdi Masyarakat, 5(2), 213-220.

Labetubun, M. A. H. (2021). Sistem Ekonomi Indonesia. Bandung : Widina Bhakti Persada.

Mahmudah. (2011). Peran Wanita Karir Dalam Menciptakan Keluarga Sakinah. PSIKOISLAMIA: Jurnal Psikologi Islam, 5(2), 217-225.
Maryani. (2011). Implementasi Syariat Islam Dalam Mewujudkan Keluarga Sakinah. Jambi: IAIN Suthan Thaha Saifuddin Jambi.

Na'im, Z. (2021). Manajemen Pendidikan Islam. Bandung: Widina Bhakti Persada.

Nasution. (1994). Rahasia Perkawinan Dalam Islam Tuntunan Keluarga Bahagia. Jakarta: Pedoman Ilmu Jaya.

Rahayu, Y. N. (2020). Program Linier (Teori Dan Aplikasi). Bandung : Widina Bhakti Persada.

Saebani. (2013). Perkawinan Dan Perceraian Keluarga Muslim. Bandung: CV Pustaka Setia.

Sinta. (2003). Wajah Baru Relasi Suami Istri. Yogyakarta: LkiS Yogyakarta.

Siregar, R. T. (2021). Komunikasi Organisasi. Bandung: Widina Bhakti Persada.

Sofyan, Y. (2020). Peranan Konseling Dosen Wali Dalam Meningkatkan Motivasi Belajar Mahasiswa Di Perguruan Tinggi Swasta Wilayah LLDIKTI IV. Jurnal Bimbingan Dan Konseling Islam, 10(2), 237-242.

Sugiyono. (2015). Metode Penelitian Pendidikan (Pendekatan Kuantitatif,. Kualitatif dan $R \& D)$. Bandung : CV. Alfabeta.

Tanjung, R. (2020). Pendampingan Usaha Oncom Dawuan Makanan Khas Kabupaten Subang Jawa Barat. Jurnal Ilmiah Pangabdhi, 6(2), 59-63.

Tanjung, R. (2022). Manajemen Mutu Dalam Penyelenggaraan Pendidikan. Jurnal Pendidikan Glasser, 6(1), 29-36.

Thobibatussaadah. (2013). Tafsir Ayat Hukum Keluarga 1. Yogyakarta: Idea Press.

Zein. (2004). Problematika Hukum Keluarga Islam Komtemporer. Jakarta: Kencana.

Zubair. (2014). Ngaji Fiqih Untuk Bekal Kehidupan Dunia-Akherat. Kediri: Santri Salaf Press Dan Lirboyo Press. 